\title{
Teacher Educators in Neoliberal Times: A Phenomenological Self-Study
}

\author{
Magnus Levinsson, University of Borås, Sweden. \\ Email:magnus.levinsson@hb.se \\ Anita Norlund, University of Borås, Sweden. \\ Email: anita.norlund@hb.se \\ Dennis Beach, University of Borås and University of Gothenburg, Sweden. \\ Email:dennis.beach@hb.se
}

\begin{abstract}
In Sweden, and most Western countries, pervasive neoliberal policies have dramatically transformed the entire education sector in a matter of decades. As teacher educators, we have experienced how neoliberal currents have pushed Swedish teacher education towards a teacher training paradigm which may risk undermining the foundations for professional judgement. Moreover, the Bologna Process and the introduction of New Public Management have had significant consequences for what it means to be a teacher educator. In this study, we present our everyday experiences of being teacher educators, immersed in a teacher education culture in Sweden which has evolved under the pressures of neoliberalism. To address these complex lived experiences, we engaged in a phenomenological first-person account. Three main themes emerged from an analysis of lived experience descriptions: (a) Alignment Slaves; (b) Audit Puppets; (c) Techno Phobes. These themes reflect different lived dimensions of being teacher educators confronted with neoliberal agendas. The paper concludes with a call for resistance to bring about change within teacher education.
\end{abstract}

Keywords: neoliberalism, teacher educator, phenomenology, self-study

\section{Introduction}

Teacher education in Sweden today is quite different from past programs that shaped us as teacher educators. Over the past two decades, we have witnessed how pervasive neoliberal policies have dramatically transformed public school teaching and education at the university level. The latest reform in Swedish teacher education has moved the curriculum back towards a teacher training paradigm that reflects ideas expressed in the 1907 Grammar School Teacher Education Act (Beach, 1995; Beach \& Bagley, 2013). The result is an increased emphasis on subject-matter knowledge and vocational practical skills (Beach \& Bagley, 2013). This regressive shift has turned the tide against the previous reform trajectory in Swedish teacher education aimed at establishing a common scientifically founded body of professional knowledge for all teachers (Beach \& Bagley, 2012; Player-Koro, 2012).

We find this development in Swedish teacher education worrisome and disturbing as our practices of providing student access to critical and theoretically 
informed knowledge have been curtailed (Nilsson Lindström \& Beach, 2015). Such professional "know-why" knowledge is of crucial importance for teachers' ability to grasp and counter the ideological and political restructuring that is going on in Sweden's schools, and that has transformed teaching into a managed, audited and commodified profession (Apple, 2001; Dovemark \& Holm, 2017; Nordänger \& Lindqvist, 2015). The neoliberal restructuring of teacher education is not restricted to a Swedish phenomenon. Apple (2001), Beach and Bagley (2013), Sleeter (2008), and Zeichner (2010) have made corresponding statements about developments in teacher education in the United States of America and in England, where neoliberal currents have pushed teacher education towards heightened standardisation, increased subject content knowledge, and pressured testing in competence-based skill areas.

In the Swedish context, neoliberal policies imply that there are good grounds upon which to believe that current teacher education is quite different from past programs. Moreover, the implementation of the Bologna Process ${ }^{1}$ (Baldwin, 2013) and the introduction of New Public Management (NPM)2 (Askling \& Stensaker, 2002) have influenced holistically the context of how teacher educators prepare Swedish teachers. These politically driven reforms in higher education have resulted in governmental control over curriculum, pedagogy, assessment practices, and management policies. This has significant consequences for what it means to be a teacher educator.

To be responsive to future teachers in Sweden's schools, and allow our program to develop, there is a need of perspectives from the inside, voices from teacher educators that counter the emerging destructive political force (Zeichner, 2007). Our following discussion presents everyday experiences in order to explore what it means to be a teacher educator in a neoliberal era. To address these complex lived experiences (van Manen, 2014), we engaged in a first-person phenomenological account (Finlay, 2012) as a way of attributing meaningful significance to space and time, and how recent neoliberal reforms in Sweden have impacted our teacher education culture.

\section{Teacher Education in Sweden}

During the Swedish Folk-Home reform period, teacher education was transformed to provide a cadre of new professionals with the knowledge and values of a progressive pedagogy, suited for modern schools and times (Beach, 2011; Beach \& Bagley, 2013). These new ideas were identified in the recommendations from the 1946 School Commission Teacher College Delegation Report (SOU, 1952) and in successive rounds of reforms up to the new millennium (see SOU, 1965, 1978, 1999). These reports shared several similarities in the recommendations and proposed reforms (Beach \& Bagley, 2012). The unifying message concerned the promotion of a common scientifically founded body of professional knowledge which is summarised as follows (see Gran, 1995; Beach, 2011):

\footnotetext{
${ }^{1}$ The Bologna Process, launched with the Bologna Declaration in 1999, involves 48 European countries in the creation of a shared European Higher Education Area that promotes mobility and employability. The Bologna Process aims, among other things, to implement (1) a comparable qualification framework divided into three cycles (bachelor, master, and doctoral studies); (2) a credit system for describing the cycles, with credits for individual modules at specific levels, depending on the year of study; and (3) common standards and guidelines for quality assurance. A key component in the Bologna Process is the establishment of learning outcomes as a basis for restructuring higher education.

${ }^{2}$ NPM is a concept used to describe the wave of public sector reforms, launched throughout the world from the 1980s and onwards, that draw on governing strategies and techniques from the private sector. Recurring characteristics of NPM reforms include (a) the use of market solutions and competition to lower costs and increase effectiveness; (b) clear target-setting to enable measurements, evaluations and comparisons of performances; and (c) increased outputfocus and output-control to align division of resources with measurable outcomes.
} 
- Scientifically developed knowledge about teaching as a profession and learning as a professionally guided activity in schools is necessary for the continuous improvement of professional knowledge for teachers and for the quality of critically reflective teaching and school development;

- Scientific autonomy is essential to this knowledge and should be developed and taught in institutions that are governed by principles of academic freedom, service to the community, and the unity of research and teaching; and

- It is a State responsibility to provide and protect the necessary preconditions for the free and open delivery of this knowledge.

Previous reforms in Swedish teacher education have also emphasized the importance of scientifically and professionally qualified teacher educators who can take an active part in this endeavour, and who were allowed to freely exercise professional judgement in the delivery of this common professional knowledge base (see SOU, 1952, 1965, 1978, 1999).

\section{Neoliberal Restructuring of Teacher Education}

The latest reform in Sweden's teacher education field, launched in the wake of a broader neoliberal transformation of the public sector, is a departure from the historical reform trajectory summarized above. The ensuing result is that a common scientific professional knowledge base has been abandoned. The Sustainable Teacher Education Commission (STEC) in 2008 (SOU, 2008), and the subsequent Swedish Government Bill (2009/10:89) implemented in 2011, prompted a drift away from theoretical educational "know-why" knowledge, back towards subject-matter knowledge and vocational practical skills (Nilsson Lindström \& Beach, 2015). The common professional knowledge is reduced to what is called the Education Science Core Component (SOU, 2008) and stretched across a broad range of content domains:

- Education organisation and preconditions, democracy's foundations;

- Curriculum theory and didactics;

- Theory of science, research methods and statistics;

- Learning and development;

- Special education;

- Social relations, conflict resolution and leadership;

- Grading and assessment;

- Evaluation and school development. (pp. 16-17)

Disciplinary pedagogy (Swedish: Pedagogik) has become marginalised and the core subdisciplines from the past (history-, sociology-, philosophy- and psychology- of education) have been removed (Nilsson Lindström \& Beach, 2015). Based on this transformation of the curriculum, an oversimplified conclusion for what is needed to teach in Sweden is as follows: teachers just need to have subject-matter knowledge and pedagogical skills to communicate this to pupils and assess their progress (Player-Koro, 2012). Player-Koro (2012) used Michael Apple's (2009) concept of conservative modernization to describe this shift in Swedish teacher education as a political project that "creates imagined pasts as the framework for imagined and stable futures" (p. 241). Both Apple (2001), and Player-Koro (2012), stressed that these changes may risk undermining the foundations for professional judgement. Furthermore, this warning has prompted us to reflect and question the challenges facing teacher educators in Sweden (cf. Apple, 2001): Will our future teachers be prepared to deconstruct the political and ideological forces surrounding them? Will they be able to connect local with global tendencies and think strategically about ways of countering the strong neoliberal hold? 


\section{Teacher Educators}

Many contemporary Swedish teacher educators struggle to identify as being invested in a strong teaching profession that is motivated to become engaged in education when compared to years past. And most disturbing to us teacher educators is that we are identified as being part of the problem. Sleeter (2008) posits:

Teacher educators must become much more aware of what neoliberalism is and how it is impacting on a range of social institutions...teacher educators have only a vague idea (or no idea) of what neoliberalism is, not recognizing it as project for restoring class power by dismantling public services. (p. 1955)

Sleeter's (2008) observation raises serious concerns about the way that the most recent teacher education reform in Sweden addressed teacher educators. The STEC inquiry (SOU, 2008) recommends a so-called "Teacher Educator Lift" to acquaint educators with the various forms of practical behavioural "know-how" knowledge introduced in the new core component. Moreover, it warns educators within disciplinary pedagogy, and general didactics (Swedish: Didaktik), to be prepared for redundancies because of the changed and reduced curriculum. The erosion of powerful theoretical knowledge in Swedish teacher education is now easily recognised in teacher educator practices.

Dunn (2016) underscores the need for all educators to fully understand the neoliberal reality that new teachers face in schools, and the ways that competition, capitalism, and commodification have transformed working conditions for teacher educators. As demonstrated by Dunn (2016), the commitment to social justice among teacher educators were not only challenged by accountability regimes, but also when they tried to deal with one of the heads of the neoliberal Hydra of teacher education (e.g. value-added measures) the others grew stronger (teacher performance assessments, competitive grant programs, educator preparation standards, evidence-based accreditations, teacher recruitment campaigns, interstate teacher assessments, teacher efficiency policies, State authority interference). This complexity is addressed in Madeloni's (2014) study that describes the experiences of a teacher educator who is pressured to participate in destructive neoliberal practices. Madeloni (2014) reveals a teacher educator who faces the risks and dangers of resisting the neoliberal agenda when questioning the pedagogical value of these practices and when trying to live up to ideals rooted in critical pedagogy.

In a review of teacher educators, Zeichner (2007) calls for more studies that explore the perspectives and voices of teacher educators in close connection to the neoliberal realities that they are facing and that frame teacher education practices at a local level. That is exactly our intention in this article. We are driven by our own lived experience reflections (van Manen, 2014) on how neoliberalism invades our daily work. Therefore, we aim to offer phenomenological descriptions of what it means to be a teacher educator in the neoliberal era.

\section{A Phenomenological Self-Study}

Exploring neoliberalization in Swedish teacher education in a self-study as teacher educators, we draw on phenomenological first-person accounts (Finlay, 2012; Madeloni, 2014) as a starting point for hermeneutical reflection. According to Finlay (2012), there is no set methodology for how a first-person account should be conducted and presented. However, personal experience descriptions need to be carefully crafted to bring forth a deeper understanding of the phenomenon: "the insight into essence of a phenomenon involves a process of reflective appropriating, of clarifying, and of making explicit the structure of meaning of the lived experience" (van Manen, 1997, p. 77). 
Thus, these first person accounts will show the lived experience of three teacher educators confronted with neoliberal agendas.

The first-person accounts offered in this article involved three authors in the: (a) telling of and talking about our personal experiences of being a teacher in different teacher education contexts; (b) crafting of anecdotes that reflect different lived dimensions of how neoliberalism influence our daily work; (c) writing, rewriting and structuring the anecdotes in different themes of lived experiences to get at the phenomena. This approach enabled us to come close to how we are experiencing our respective teacher education settings, but it also helped us to move beyond our individual experiences and accomplish a joint first-person account. This shared representation potentially shows experiences that are recognizable to other teacher educators living the consequences of neoliberalism.

\section{Crafting of Anecdotes}

According to Eilifsen (2011), a powerful anecdote has potential to reveal something in the experience that is familiar and recognizable to others: it "allows us to experience existence by letting the moment linger and grip the slippage" (p. 8). Our anecdotes provide the foundation for our phenomenological self-study with the intention to reveal concrete lived experiences and bring the phenomenon of focus closer (van Manen, 2014). Through these anecdotes, we present the "pedagogical here and now" (Foran \& Olson, 2008) of being a teacher educator immersed in a place where teacher education culture has evolved under the pressures of neoliberalism.

The lived experiences capture specific moments of the neoliberal reality that we experienced in different teacher education settings at the University of Borås, Sweden. At our faculty, there are approximately 65 educators $^{3}$ involved in three separate education programs for preschool, primary, and secondary teachers, and yearly about 250 student-teachers graduate from these programmes. However, the anecdotes in this article, represent a blend of experiences of being an educator in these programmes, and focus on the broader teacher education landscape that has emerged in the wake of the Bologna Process (Fejes, 2008) and the introduction of NPM (Askling \& Stensaker, 2002). Everyday work in our teacher education program does not only involve collaborations with students and fellow teacher educators, but also, and to an increasing extent, encounters with managers, quality-assurance officers, administrators, coordinators, and assessors.

We took a mutual responsibility to question, write, and rewrite the anecdotes. In this process, we engaged in hermeneutic conversations to reflect on our experiences and grasp the deeper meanings of these experiences (van Manen, 1997). The emphasis was on exploring the phenomena through several lived dimensions-lived time (temporality); lived space (spatiality); lived body (corporeality); and lived human relations (intersubjectivity) — to bring about descriptions that capture the complexities and ambiguities involved with the problems in focus (van Manen, 2014). As a result of these hermeneutic conversations, three main themes of lived experience emerged. Each anecdote in these themes has been ascribed to one of the authors to facilitate a strong and addressive meaning, even though all anecdotes have been jointly crafted. In the

\footnotetext{
${ }^{3}$ Three categories identified in Swedish teacher education: (1) Teachers at departments where teacher education is the main activity; (2) Teachers at other departments who participate in teacher education; (3) Teachers in schools or preschools who participate in teacher education. At our department, teacher education is mainly staffed with the first category of teachers, even though most of them of have significant experience of school teaching.
} 
following sections, we will present three themes-(a) Alignment Slaves; (b) Audit Puppets; (c) Techno Phobes-which reflect different lived experiences of how neoliberalism influences our daily work.

\section{Alignment Slaves}

Pervasive neoliberal reforms have turned teacher education into a matter of political control. The ensuing result is that the best teacher educators are now the ones who are able to steer the whole educational process towards the predefined learning outcomes that has been reproduced in our policy documents since the Bologna Process (Baldwin, 2013; Fejes, 2008). A key component involved in this neoliberal pursuit for control is the principle of constructive alignment - the Bologna Process's ally — which has had a profound impact across higher education institutions in Sweden (Wickström, 2015). The constructive alignment model entails that educators should start with the outcomes they intend students to learn by specifying them in advance, and then align teaching activities and assessment to those intended learning outcomes (Biggs \& Tang, 2011).

In many different ways, teacher educators in Sweden are pressured to comply with this ideal when planning, implementing, and evaluating teaching, and Magnus can testify that this has significant consequences for what it means to be a teacher. Magnus has experienced how the excessive use of the constructive alignment model in Swedish teacher education has transformed teaching into a technical exercise:

When we teacher educators meet to plan, we place great emphasis on specifying learning outcomes by the book, and on showing, on paper, how our teaching activity and assessment are outcome aligned. We spend hours on rephrasing a particular learning outcome and on discussing how it best should be assessed. We are driven, and obsessed, by the need to have our courses approved by the Education Committee. This is blind compliance, and we are bending to great control and results in a "paint by numbers" feel to our existence as teachers. We mechanically follow a given formula for "good education," and every step we take to prepare for teaching is predictable. Sometimes, I get completely immersed in this technical practice - seeing every aspect of teaching through the lens of constructive alignment. I take on a role that is more reminiscent of the accountant's assistant than that of the professional teacher. In light of such a role we share the false experience that the course is somehow "ready" because the plan emerges once everything is in perfect order...on paper. I reread the plan and there is this feeling, not of teacher satisfaction, however, but of frustration that we, once again, have neglected crucial educational questions about purpose, content, and pedagogical relations. The fact that we have not discussed how we understand the literature, what educational meaning we want to foster among students, and how our course will lead to a desirable formation of new teachers. I am empty at the end of the collegial gathering-empty.

Magnus portrays a teacher educator who experiences the collegial planning for teaching as a robot-like activity_lived bodies that work mechanically together, without original thought, and that seem programmed to follow readymade curriculum design processes. Magnus is experiencing what Heidegger (1966) refers to as being immersed in "calculative thinking." It is a mode of revealing that alienates us from things 
themselves, rendering teaching into a technical exercise and enables external control (cf. Bonnet, 2002).

Simultaneously, Magnus seems to be aware of what is at stake: he plunges hours into constructing learning outcomes and assessments to get the Education Committee's approval - the abstract body controlling the lived in-flesh body-whose task is to review syllabi at the department. It is in relation to this abstract body that Magnus sometimes lives through space and time in a way that he claims is more suitable for an "accountant's assistant" than for a professional teacher: that an essential part of teaching takes place on a piece of paper and that a teacher's core professional duties are completed once perfect constructive alignment is established on that sheet. As Wickström (2015) points out, "there is a risk that the use of the alignment model reduces course development processes to paperwork" (p. 14). This danger is real for Magnus and his frustration over neglecting crucial educational questions is even more palpable as he continues:

For those of us who have strong roots in the Nordic teaching tradition, and still are committed to the practice of Bildung, the constructive alignment model seems to be a simplistic ideal, and, in practice, it really has come to mean educational bullshit! But teacher educators have no say in educational decisionmaking anymore. Our core professional duties have been transformed into something that anyone can do. We are surrounded by managers, quality assurance officers and coordinators, not by pedagogues, and they seem to embrace the alignment model. The other day, I was confronted by a coordinator who had serious questions about an upcoming revision of one of our programmes. He just walked into my office and declared that we had failed to adhere to local policies. I apologized for our shortcomings, and shamefaced, I nodded in agreement to all points in his extensive revision list, which among other things required us to establish a program rubric - an extensive grid system - to explicitly align all the learning outcomes and assessments in each individual course with the broader program-level goals. I felt small and inferior, almost like a little schoolboy who had forgotten to do his homework, and who was forced to stand in the naughty corner. I am no longer allowed to teach.

Magnus seems to experience a displacement of power from himself to the new positions that have emerged in the wake of NPM (Askling \& Stensaker, 2002). His description of the encounter with the education coordinator reveals bodily, relational, and spatial dimensions of this shift: resigned to the constructive alignment expertise of the coordinator, who imposes this ideal on him, Magnus' office is turned into a naughty corner and he embodies a caught school boy who nods submissively, ashamed of his obvious mistakes under the gaze of the authoritarian teacher.

Magnus' story also carries an intense feeling of being unneeded and neglected. What Magnus is and what he knows - a teacher educator with strong roots in the Nordic Didaktik tradition (Brante, 2016) - have no place in the outcome-based constructive alignment landscape. His autonomy to associate different meanings with given matters, and the freedom of Bildung emerging in situated encounters between student and content has been lost (cf. Hopmann, 2007). As Bonnett (2002) points out, "standards are 'met' or 'not' met, prespecified learning goals are 'achieved' or 'failed in', teaching and teachers are accounted 'effective' or 'ineffective', and the authentic life of the mind is likely either bypassed, or worse, destroyed" (p. 240). Magnus feels that he is no longer allowed to teach. 


\section{Audit Puppets}

The rise of an audit culture (Power, 1999) within higher education has by no means escaped teacher educators in Sweden. Most significantly, since the introduction of the European Standards and Guidelines for Quality Assurance (ESG, 2015) initiated by the Bologna Process (Huisman \& Westerheijden, 2010) - audits have developed into a cornerstone in the quality assurance of higher education. At our university, these standards and guidelines have prompted the use of continuous program and course evaluations, recurring local education evaluations, and national-education evaluations conducted by the Swedish Higher Education Authority (UKÄ). Swedish teacher educators are involved in different kinds of audit activities more or less on a regular basis. However, the emergence of audits has been identified as a logical outgrowth of the increased neoliberalism, with significant consequences for teachers' work and professional identities (Apple, 2005; Solbrekke \& Englund, 2011). Dennis describes what it is like to be immersed in a destructive audit culture:

When the UKÄ review approaches, the nervousness at the department is palpable, especially among those educators who have been selected to answer to the assessment panel. This anxiety is fueled by managers and quality assurance officers who threaten that we will lose our rights to award degrees if we fail to follow the "rules of the game," in what is a pronounced competition with other institutions. It feels like our own existence is at stake, and many teachers dare not do anything and nervously fall in line. Many resources are invested in preparing and calming the teachers who participate. Last year, a manager asked me if I could help out with a kind of "dry run" that was supposed to resemble UKÄ's audits. I said I could, but first and foremost to assist my worried colleagues. I reviewed drafts of self-assessments and played the role of an assessor in simulated interviews with my colleagues. But I wrestled with uncertainty. As I reached out to help my colleagues, I made myself into a puppet in audit society's service. The whole thing resembled a trial, where I was the prosecutor - with all the hard evidence on my side - and my colleagues had to sit on the accused's bench, alone and defenceless. As they tried to answer my critical questions, their voices became rather squeaky and they kept looking down, searching for answers in their papers. This was not about helping my colleagues. As I embraced my assigned role and exposed their weaknesses, I made things worse. We should take a greater responsibility for questioning this audit mania, rather than supporting it.

Dennis' story about UKÄ audits entails significant relational, spatial, and bodily experiences: auditing teacher education programs discloses itself in a competition arena, where managers, and quality assurance officers, appear as harsh coaches, who motivate their squad by threatening them with the ultimate cost of a defeat. This enforced contest jeopardized Dennis and his colleagues' very existence as teachers, and left an impending fear producing collegial-docile bodies that nervously fall in line.

The dry run - the "friendly" audit game - set up by managers evokes spatial experiences of being in a trial, where Dennis experiences himself as a prosecutor whose ascendancy brings about squeaky voices, downward eyes, and desperately searching hands among those sitting on the accused's bench. Dennis and his colleagues have become transparent, but at the same time empty and unrecognisable to themselves (cf. Ball, 2015). Dennis has been transformed into an audit puppet: an involuntary position that seems to be lived as a double betrayal, not just of his colleagues, who are 
compelled to expose their weaknesses, but of himself for not taking action against the audit mania. The collegial damage that audits cause in Swedish teacher education is further illustrated as Dennis describes how the audit culture has increased the use of different kinds of evaluations:

We are required to evaluate both courses and programs, based on a number of fixed categories, and present this "data" in a report that is posted on the university website. Auditing time means evaluation hysteria at the end of each term. We are caught up in it and we drown in administration and documentation. There is already too little room for collegial reflection. These evaluations are high stakes. They represent an important measure of the university's quality assurance efforts, and last year, those who forgot or did not obtain sufficient student responses had to fabricate course reports afterwards. The important thing was that these were visible to assessors; that it appeared that we were in control. However, the majority of my students do not read these reports. I wonder, therefore, about the educational value of educators together producing multiple course reports each term. Some of us have developed strategies to produce these reports with less effort: we construct empty shells with a minimal amount of data that look good on the surface. Although this tactic frees up time for more meaningful activities, it needs to be kept quiet. When you circumvent the surveillance, you feel like a criminal waiting to be found out. For what will be discovered at the recurring audits-will they find the course mismanaged and who will be held ultimately responsible for this?

Dennis experiences the many requirements for evaluation as "hysteria:" he is enforced to perform for the audit system itself, rather than for the students, and he drowns in a sea of documentation and administration, unfairly competing with his ability to fulfil his daily teaching responsibilities. Dennis seems to face what Rinehart (2016) has observed, that "Neoliberal and audit culture policies devalue the work that teachers do with individual students" (p. 32). The feeling of being immersed in detached educational audit practices is tangible in Dennis' fabrication description of course reports that was imposed on educators before an upcoming review. The only reason for doing this exercise was to satisfy visiting assessors with an image of a program in control, and the fact that his students actually do not read these reports makes it appear as even more absurd.

To act in the best interest of the students, Dennis and some of his colleagues have started to generate course reports with less effort. However, when employing this strategy, the audited teacher education program reveals itself as a crime scene: Dennis and his fellow teacher educators are acting and feeling like offenders on the run, afraid of being caught and punished for fraud. This constant visibility built into teacher educators' everyday work seems to produce accompanying anxiety and uncertaintysomething that Lazzarato (2009) calls "the micro-politics of little fears" (p. 120). The audit culture in Swedish teacher education produces lived experiences that hardly can be associated with teacher educators who are guided by professional responsibility (cf. Solbrekke \& Englund, 2011).

\section{Techno Phobes}

In accordance with neoliberal competitiveness (Brown, Halsey, Lauder, \& Wells, 1997) the requirement to use modern information and communication technology (ICT) has also emerged in Swedish teacher education (Player-Koro, 2013). 
This development is fueled by a number of actors - the Organisation for Economic Cooperation and Development (OECD), governments, companies, researchers - to adapt education to an uncertain knowledge society, and enhance national competitiveness in a globalized economy (Egea, 2014). ICT also perfectly meets the learner-centered and outcome-based curriculum following the Bologna Process: "It is a common belief that ICT could be the driving force in this change of paradigm" (Albino \& ArmendárizInigo, 2010, p. 216). ICT tools are assumed to provide an attractive, effective, and flexible way of learning, and to enable customized educational programs that encourage the development of so-called $21^{\text {st }}$ century skills (Bayne, 2015; Egea, 2014). However, the increased requirements to use ICT bring about changes to teachers' work that are not all for the good (Player-Koro, 2013). Anita describes how teacher educators are held accountable for the current implementation of new digital tools and high-tech facilities in Swedish teacher education:

The setting up of Active Learning Classrooms and the introduction of digital assessment are rarely initiated by the teaching staff. Yet, when new arrangements have been introduced, we are invited to seminars on how new technologies are supposed to work, where we always seem to hear, "well let's see how you can adapt your teaching to this modern tool." We have not requested these changes, but we feel guilty and liable when these novelties are not used to the full extent. Furthermore, the funding allocation to make such purchases leaves us feeling even worse, empty even, for it hurts to watch our limited resources go down the drain. Last year I was recommended by managers to attend an ICT conference. Ironically, the keynote broadcast via link failed due to technical problems. Later that day, ICT promoters accused teacher educators for avoiding new digital tools because of fear! Fear?! My whole body was trembling with anger. They acted as self-appointed psychologists with the right to make judgements about our inner lives. I do not see a bunch of techno-phobic colleagues around me! My daily teaching is quite innovative, but here I got portrayed as a frightened luddite. This incident has made me self-doubt my practice - maybe I am an outdated teacher who really needs a total makeover to fit in our modern high-tech society? But still, something is seriously wrong when every sign of criticism is dismissed as fear. I want to explain that any scepticism I have is not about fear; rather, it is that my teaching already works well enough, and, most importantly, that the current technology hype is not all that good when it meets the realities of my classroom.

Anita feels that she is individually blamed for what promoters seem to consider as an anxious reception of ICT in teacher education (cf. Player-Koro, 2013). She is confronted with the message that it is educators who prevent new technology from modernizing teaching and learning at the university. Even though Anita has not requested these changes, she finds herself guilty and still accountable. This feeling grows even stronger by the fact that considerable resources are wasted on barely used facilities and tools.

Anita, who holds a moderate degree of appreciation, is depicted as being afraid, and that she is avoiding ICT simply because of fear. For Anita, this is a source of frustration because every sign of criticism seems to be labelled as technological fear, and this makes her even more suspicious. The incident at the conference provokes relational, temporal, bodily, and spatial experiences: promoters appear as self-appointed psychologists who diagnose educators as technophobes, and seem to position Anita in a 
prehistoric body that has yet not reached far enough in its evolution towards a fullblown ICT user. This is lived as a considerable violation-Anita's body is trembling with anger - which seems to elicit self-doubt; sometimes Anita feels like an outdated teacher, totally misplaced in the quest for a cutting-edge program.

The anecdote portrays a teacher educator who is being in the midst of a digital hype to which it is impossible to be critical-it is what Egea (2014) refers to as an "inevitability ethos" (p. 277). According to Selwyn (2007), a critical attitude is not even found among researchers. However, studies have revealed that the neoliberal ICT project repurposes teachers away from education (Bayne, 2015). Anita touches on this issue:

Seminar presentations include many rhetorical questions like: "What would happen if we used the whole hallway at campus as a big interactive whiteboard?" The response is often expressed with a cunning smile, but with no further answers other than that ICT will revolutionize learning. It is all this talk about learning, just learning in general and very vaguely. But my work cannot be fully understood in this new language of learning. That education involves a teacher, revolves around a content, and has a broader purpose have more or less been forgotten. We are being reduced to ICT coaches who should support the individual's quest for attractive competences, commodities that can be sold and exchanged in the marketplace. But when I try to bring these downsides into the discussion, I am confronted with further questions, sometimes even by fellow teacher educators: "What do you have against learning?" The technology drive has really caused a divide between teachers, between those of us who rely on traditional approaches, and those who embrace new digital tools. I am finding that we do not speak the same language anymore.

Anita seems to experience what Biesta (2012) refer to as the "learnification" of education: a pervasive learning discourse, fueled by the current technology drive, and closely linked to the neoliberal agenda. According to Egea (2014) this is "a mode of dominating reality, in order to be measured, exploitable and accountable" (p. 278). For Anita, this new language of learning appears to obscure fundamental educational questions that situate learning in an educational context, and that define her work as a teacher: she is being reduced to a modern coach whose main task is to encourage the individual students' development of $21^{\text {st }}$ century skills.

When Anita tries to highlight this language barrier she is confronted with rhetorical questions as answers magnifying her suspicion. And even though these questions probably are posed in a friendly manner, they appear to be quite demanding: it is up to a teacher educator to come up with what miracles would happen if the hallway was used as a big interactive whiteboard. According to Anita she has to explain and defend her view of education, even in front of colleagues. The current ICT hype, accompanied by the emerging learning discourse, seems to alter relations between teacher educators at Anita's department, between teachers who appreciate new technology, and teachers who prefer traditional approaches (cf. Player-Koro, 2012). Neither do they seem to understand each other anymore, nor share a common understanding of teacher education.

\section{Discussion}

The anecdotes shared in this article show that the neoliberal turn in Swedish teacher education has substantial consequences for the fundamental structure of a 
teacher educator's lifeworld (van Manen, 1997). The practices that have emerged in the wake of the Bologna Process (Baldwin, 2013) and the introduction of NPM (Askling \& Stensaker, 2002) bring about significant spatial (e.g. "naughty corners;" "crime scenes;" "competition arenas"), bodily (e.g. "submissive nods;" "squeaky voices;" "trembling bodies"), temporal (e.g. "false sense of "ready' courses;" "never-ending documentation and administration;" "outdated professional identities"), and relational experiences (e.g. "authoritarian managers and coordinators;" "betrayed colleagues and students;" "incriminating technology promoters"). These lived experiences can hardly be associated with autonomous teacher educators who are guided by professional judgement and responsibility (cf. Solbrekke \& Englund, 2011). Rather, they reflect teachers whose lived experiences reveal they are being turned away from education, and whose professional duties and identities are being fundamentally changed.

Previous research has shown that neoliberal policies have prompted an erosion of theoretical professional knowledge in Swedish teacher education (Beach \& Bagley, 2012; Nilsson Lindström \& Beach, 2015). The phenomenological first-person accounts offered in this paper suggest that increased neoliberal pressures in Sweden are undermining teacher educators in practice. They no longer appear to be part of institutions that are governed by principles of academic freedom, service to the community, and the unity of research and teaching (cf. Beach \& Bagley, 2012). Future public school teachers seem no longer to be taught by autonomous and responsible educators who are allowed to exercise their professional judgment, removed from political and ideological interference. As Solbrekke and Englund (2011) point out, "mechanisms of accountability seem to be 'triumphing' over responsibility in today's governance systems" (p. 847). The lived experience descriptions denote that teaching in Swedish teacher education has been transformed from a moral, pedagogical, and ethically responsible profession to a managed, audited, and commodified activity (cf. Nilsson Lindström \& Beach, 2015).

The neoliberal forces confronting the teacher educators in this article prompt the following question: Are professionally and scientifically qualified educators neither desired nor required in current teacher education in Sweden? Neoliberalism is the end of teaching as they experience it: their work has been transformed into something that anyone can do, and others - managers, quality assurance officers, assessors, coordinators and administrators - have already taken over. The neoliberal practices that have emerged in Swedish teacher education do not call for an independent group of intellectuals who are committed to the creation of a strong teaching profession. Rather, these practices require individual "doers" who are willing to be controlled by others, and who are ready to implement the new outcome-based curriculum, produce constructive alignment, prepare education programmes for audits, follow quality assurance regulations, administer course evaluations, and make use of new technology. Teacher educators in Sweden have become like teacher educators in other countries (cf. Dunn, 2016; Madeloni, 2014; Sleeter, 2008), victims of the neoliberal assault on teacher education.

The anecdotes offered above portray teacher educators who are under constant pressure to become neoliberal subjects. At the same time, neglecting the critical role that education can, and should, be playing for prospective teachers in a neoliberal time (Apple, 2001, 2009). The educators taking part in this study are, however, well aware of the neoliberal reality that new teachers enter (cf. Sleeter, 2008), and that it is critical what they do to empower them to develop and control their practices professionally (Nilsson Lindström \& Beach, 2015). It is this awareness of the potential value of education that appears to cause the alienation and the frustration they feel when they are 
forced to participate in destructive neoliberal practices (cf. Madeloni, 2014). Nevertheless, teachers educators are the ones who must begin to resist, and bring professional responsibility back in as a guiding principle in their practices, in order to provide new teachers in Sweden's schools with opportunities to follow their example and start doing the same when they face the pressures of neoliberalism (Dunn, 2016; Solbrekke \& Englund, 2011).

Resistance does exist. It exists in the form of the subtle ones described above, such as secret attempts to find ways around the surveillance or criticism of the emerging learning discourse, and also in terms of research. In previous studies, the authors have all, in different ways and in other collaborations, investigated how neoliberal currents have influenced educational policy and practice (e.g. Beach, 2018; Levinsson, 2013; Norlund, 2014). They have, however, primarily investigated the consequences that neoliberalism has had for others. In this discussion, we have engaged in phenomenological first-person accounts, with the shared ambition of making different stakeholders see the lived consequences of neoliberalism from our teacher educator perspective. We hope that our voice, a common-united voice, from the inside, can form the basis for reflection and discussion among teacher educators and, most importantly, be the starting point for a more organized and joint resistance, that in the long run, will bring about changes within teacher education.

\section{References}

Albino, P. M. B. \& Armendáriz-Inigo, J. E. (2010). On the utility of ICT in the European higher education area: The Bologna Process and its implications in the innovation of the teaching and learning process. In M. D. Lytras, P. O. De Pablos, D. Avison, J. Sipior, Q. Jin, W. Leal, L. Uden, M. Thomas, \& D. Horner (Eds), Tehnology enhanced Learning: Quality of teaching and educational reform (216-222). Berlin: Springer.

Apple, M. W. (2001). Markets, standards, teaching, and teacher education. Journal of Teacher Education, 52(2), 182-196.

Apple, M. W. (2005). Education, markets, and an audit culture. Critical Quarterly, $47(1-2), 11-29$.

Apple, M. W. (2009). Can critical education interrupt the right? Discourse: Studies in the Cultural Politics of Education, 30(3), 239-251.

Askling, B. \& Stensaker, B. (2002). Academic leadership: Prescriptions, practices and paradoxes. Tertiary Education and Management, 8(2), 113-125.

Baldwin, R. (2013). Changing practice by reform: The recontextualisation of the Bologna Process in teacher education. Diss. Gothenburg: Acta Universitatis Gothoburgensis.

Ball, S. J. (2015). Education, governance and the tyranny of numbers. Journal of Education Policy, 30(3), 299-301. 
Bayne, S. (2015). "What's the matter with 'technology-enhanced learning'?" Learning, Media and Technology, 40(1), 5-20.

Beach, D. (1995). Making sense of the problems of change: An ethnographic investigation of teacher education reform. Diss. Göteborg: Acta Universitatis Gothoburgensis.

Beach, D. (2011) Education science in Sweden: Promoting research for teacher education or weakening its scientific foundations? Education Inquiry, 2(2), 207220.

Beach, D. (2018). Structural injustices in Swedish education. Singapore: Palgrave MacMillan.

Beach, D. \& Bagley C. (2012). The weakening role of education studies and the retraditionalisation of teacher education. Oxford Review of Education, 38(3), 287303.

Beach, D. \& Bagley, C. (2013). Changing professional discourses in teacher education policy back towards a training paradigm: A comparative study. European Journal of Teacher Education, 36(4), 379-392.

Biesta, G. J. J. (2012). Giving teaching back to education: Responding to the disappearance of the teacher. Phenomenology \& Practice, 6(2), 35-49.

Biggs, J. \& Tang, C. (2011). Teaching for quality learning at university: What the student does ( $4^{\text {th }}$ Edition). Glasgow: Society into Research in Higher Education.

Bonnet, M. (2002). Education as a form of the poetic: A Heideggerian approach to learning and the teacher-pupil relationship. In M. A. Peters (Ed.), Heidegger, education and modernity (229-243). Lanham, MD: Rowan Littlefield, Inc.

Brante, G. (2016). Allmän didaktik och ämnesdidaktik - en inledande diskussion kring gränser och anspråk [General didactics and subject didactics: An initial discussion of the limits and claims]. Nordisk Tidskrift för Allmän Didaktik, 2(1), $52-68$.

Brown, P., Halsey, A. H., Lauder, H., \& Wells, A. S. (1997). The transformation of education and society: An introduction. In A. H. Halsey, H. Lauder, P. Brown, \& A. S. Wells (Eds.), Education culture economy society (1-44). Oxford: Oxford University Press.

Dovemark, M. \& Holm, A-S. (2017). The performative culture in Swedish schools and how teachers cope with it. In K. Borgnakke, M. Dovemark, \& S. M. da Silva (Eds.), The postmodern professional: Contemporary learning practices, dilemmas and perspectives (33-52). London: Tufnell press.

Dunn, A. H. (2016). "It's dangerous to be a scholar-activist these days:” Becoming a teacher educator amidst the hydra of teacher education. Teacher Educational Quarterly, 43(4), 1-30. 
Egea, O. M. (2014). Neoliberalism, education and the integration of ICT in schools. A critical reading. Technology, Pedagogy and Education, 23(2), 267-283.

Eilifsen, M. (2011). Capture the unexpressed: Anecdote as a device in hermeneutic phenomenological research. Indo-Pacific Journal of Phenomenology, 11(1), 19.

ESG (2015). Standards and guidelines for quality assurance in the European higher education area. Brussels, Belgium.

Fejes, A. (2008). European Citizens Under Construction - the Bologna Process Analysed from a Governmentality Perspective. Educational Philosophy and Theory, 40(4), 515-530.

Finlay, L. (2012). 'Writing the pain': Engaging in first-person phenomenological accounts. Indo-Pacific Journal of Phenomenology, 12(sup2), 83-91.

Foran, A. \& Olson, M. (2008). Seeking pedagogical places. Phenomenology \& Practice, 2(1), 24-48.

Gran, B. (1995) Professionella lärare? Lärarförbundets utvärdering av grundskollärarutbildningen [Professional teachers? The national union of teachers' evaluation of teacher education for the common comprehensive school]. Stockholm: Lärarförbundet.

Heidegger, M. (1966). Discourse on thinking, (J. Anderson \& E. Freund, Trans.). New York: Harper \& Row.

Hopmann, S. T. (2007). Restrained teaching: The common core of Didaktik. European Educational Research Journal, 6(2), 109-124.

Huisman, J. \& Westerheijden, D. F. (2010). Bologna and quality assurance: Progress made or pulling the wrong cart? Quality in Higher Education, 16(1), 63-66.

Lazzarato, M. (2009). Neoliberalism in action: inequality, insecurity and the reconstitution of the social. Theory, Culture and Society, 26(6), 109-133.

Levinsson, M. (2013). Evidens och existens. Evidensbaserad undervisning $i$ ljuset av lärares erfarenheter. Diss. Göteborg: Göteborgs universitet.

Madeloni, B. (2014). From a whisper to a scream. Ethics and resistance in the age of neoliberalism. Learning and Teaching, 7(1), 79-91.

Nilsson Lindström, M. \& Beach, D. (2015). Changes in teacher education in Sweden in the neo-liberal education age: Toward an occupation in itself or a profession for itself? Education Inquiry, 6(3), 241-258.

Nordänger, U. K. \& Lindqvist, P. (2015). Lärares förväntningar på yrket-bilder av handlingsfrihet 1993-2013. Pedagogisk Forskning i Sverige, 20(3-4), 195-220. 
Norlund, A. (2014). When teachers are confronted with ideological aspects of their profession. Policy Futures in Education, 12(4), 527-542.

Player-Koro, C. (2012). Reproducing traditional discourses of teaching and learning mathematics: Studies of mathematics and ICT in teaching and teacher education. Diss. Göteborg: Göteborgs universitet.

Player-Koro, C. (2013). Hype, hope and ICT in teacher education: a Bernsteinian perspective. Learning, Media and Technology, 38(1), 26-40.

Power, M. (1999). The audit society: Rituals of verification. Oxford: Oxford University Press.

Rinehart, R. E. (2016). Neoliberalism, audit culture, and teachers: Empowering goal setting within audit culture. Teachers \& Curriculum, 16(1), 29-35.

Selwyn, N. (2007). Web 2.0 applications as alternative environments for informal learning - a critical review. Paper for OECD-KERIS international expert meeting on ICT and Educational Performances. Cheju Island, South Korea.

Sleeter, C. (2008). Equity, democracy and neo-liberal assaults on teacher education. Teaching and Teacher Education, 24(8), 1947-1955.

Solbrekke, T. \& Englund, T. (2011). Bringing professional responsibility back in. Studies in Higher Education, 36(7), 847-861.

SOU (1952:33). Den första lärarhögskolan. Betänkande utgivet av 1946 års skolkommission. Stockholm: Ecklasiastikdepartementet.

SOU (1965:29). Lärarutbildningen. 1960 års lärarutbildningssakkunniga. Stockholm: Ecklasiastikdepartementet.

SOU (1978:86). Lärare för skola i utveckling. Betänkande av 1974 års lärarutbildnings sakkunniga. Stockholm: Utbildningsdepartementet.

SOU (1999:63). Att lära och leda. En lärarutbildning för samverkan och utveckling. Lärarutbildningskommitténs slutbetänkande. Stockholm: Utbildningsdepartementet.

SOU (2008:109). En hållbar lärarutbildning. Betänkande av Utredningen om en ny lärarutbildning (HUT 07). Stockholm: Fritzes.

Swedish Government Bill. (2009/10:89). Bäst i klassen. Stockholm: Regeringskansliet.

van Manen, M. (1997). Researching lived experience. ( $2^{\text {nd }}$ Edition.) Ontario: Althouse Press.

van Manen, M. (2014). Phenomenology of practice: Meaning-giving methods in phenomenological research and writing. Walnut Creek, California: Left Coast Press. 
Wickström, J. (2015) Dekonstruerad länkning. En kritisk läsning av constructive alignment inom svensk högskolepedagogik och pedagogisk utveckling. Utbildning \& Demokrati, 24(3), 1-23.

Zeichner, K. (2007). Accumulating knowledge across self-studies in teacher education. Journal of Teacher Education, 58(1), 36-46.

Zeichner, K. (2010). Competition, economic rationalization, increased surveillance, and attacks on diversity: neo-liberalism and the transformation of teacher education in the US. Teaching and Teacher Education, 26(8), 1544-1555. 